\title{
Physicochemical properties and major elements contents of Algerian honeys from semi-arid regions
}

\author{
Lynda Haouam ${ }^{1,2 *}$, Ali Tahar ${ }^{2}$, Hélène Dailly ${ }^{3}$, Anissa Lahrichi ${ }^{4}$, Abdellah Chaqroune $^{4}$, Cherif Abdennour $^{2}$ \\ ${ }^{1}$ Department of Biology, Faculty of Natural and Life Sciences, University of Souk Ahras, Souk-Ahras 41000, Algeria; ${ }^{2}$ Laboratory of Plant \\ Biology and Environment, Department of Biology, Faculty of Sciences, University Badji Mokhtar-Annaba, Annaba 23000, Algeria; ${ }^{3}$ Beekeeping \\ Centre of Research and Information (CARI), Place Cross South 4bte L7.07.09, 1348 Louvain-La Neuve, Belgium; ${ }^{4}$ Faculty of Medicine and \\ Pharmacy. University Sidi Mohammed Ben Abdellah. BP 2626, Route d'Imouzzer 30000 Fez. Morocco
}

\section{A B S T R A C T}

\begin{abstract}
The aim of this study is to characterize Honey from semi-arid regions of North-east Algeria. Therefore, twenty artisanal honey samples (13 multifloral and 7 unifloral) were collected and then characterized on the basis of their physico-chemical parameters (free acidity, $\mathrm{pH}$, moisture content, electrical conductivity, Ash and sugar content) and the mineral composition (Ca, $\mathrm{K}$, Mg and $\mathrm{Na}$ ). Results showed that these regions are characterized by low moisture and low percentage of major elements. However, potassium was the most abundant of all elements determined. A statistical analysis was carried out to identify the most significant parameters and the chemometric methods used such as principal component analysis (PCA) and cluster analysis (CA) in order to classify the three types of honeys. The PCA indicated that the cumulative variance was $81.74 \%$ with the first four principal components variables. Therefore, the use of chemometric methods on the physico-chemical parameters and major elements is not a useful tool to characterize different types of honey originates regions with the same climate.
\end{abstract}

Keywords: Honey; Physicochemical properties; Major elements; Chemometric; Semi-arid climate; Algeria

\section{INTRODUCTION}

Honey is generally defined as "The natural sweet substance produced by honey bees from the nectar of blossoms or from secretion of living parts of plants" (Ajlouni and Sujirapinyokul, 2010). It is a highly saturated water solution composed of a mixture of carbohydrates, such as fructose $(25-45 \mathrm{~g} / 100 \mathrm{~g})$, glucose $(25-37 \mathrm{~g} / 100 \mathrm{~g})$, maltose $(2-12 \mathrm{~g} / 100 \mathrm{~g})$, sucrose $(0.5-3 \mathrm{~g} / 100 \mathrm{~g})$ with traces of many other sugars depending on the floral source and water $(15-18 \mathrm{~g} / 100 \mathrm{~g})$, in addition to acids, proteins and minerals (Freitas et al., 2006).An extensive range of physicochemical parameters are used, such as color, sugar content, $\mathrm{pH}$, moisture content and mineral analysis, to determine the quality and the type of honey being produced (Conti, 2000). The physical and chemical composition of honey is dependent on its origin and thus the composition of nectar and honeydew honeys differ (Lachman et al., 2007). Honey contains a variety of metals. The maximum limit for mineral content in honey is $0.6 \mathrm{~g} / 100 \mathrm{~g}$ (Bogdanov et al., 1999).
In different honey types, metal concentrations depend on whether it is a light or a dark honey types. Dark honey types always contain higher levels of minerals (Vanhanen et al., 2011) and depend largely on the elemental composition of flowers, with regard to their botanical and geographical origin (Pisani et al., 2008; Rashed and Soltan, 2004). Honey composition is influenced by the nectar types that the honey bee used, geographical ecology (climatic and soil) and the contribution of the beekeeper (Belay et al., 2013). The mineral and trace element concentration in honey samples could give an indication of environmental pollution and its geographical origin (Anklam, 1998).

Recently, the analysis of metal content has been a method of discriminating honey origin, and an attractive substitute instead of traditional method and some expensive and complex new parameter determinations (De AldaGarcilope et al., 2012).

Different methods are used by many authors to determine mineral and heavy metal contents of honey (Torres et al.,

\footnotetext{
${ }^{*}$ Corresponding author:

Lynda Haouam, Univ Souk Ahras, Faculty of Natural and Life Sciences, Department of Biology, 41000 Souk Ahras, Algeria.

Tel.: 002136684156 47. E-mail: I.haouam@univ-soukahras.dz
}

Received: 12 April 2015; $\quad$ Revised: 28 November 2015;

Accepted: 29 November 2015;

Published Online: 05 Decemeber 2015 
2005; Hernandez et al., 2005; Tuzen et al., 2007; Pisani et al., 2008; Madejczyk and Baralkiewicz, 2008; Sun et al., 2011). Spectroscopic techniques are the most popular methods used to determine mineral content of honey, such as F-AAS, ICP-OES and ICP-MS. Owing to their wide range linearity, superior sensitivity and high efficiency (Yücel and Sultanoğlu, 2013).

Algeria is a broad territory extends over an area of $2381741 \mathrm{Km}^{2}$ and is the second largest country in Africa. Its climate is very different between regions (NorthSouth, East-West). Its Mediterranean climate covering the northern part embracing the shoreline and the Tell Atlas (hot-dry summer and cold-humid winter), the semi-arid highlands in the center of the country, and the Sahara desert in the south. Thus, the climate diversity has led to diversified flora along the country. As a result, the beekeeping activities are distributed within the country, especially in the northern zone.

Among the techniques of classification, which are based on the similarity between samples, are the commonly used multivariate statistical techniques; the principal component analysis (PCA) and the cluster analysis (CA). Such techniques are exploratory and descriptive method, which aid in reducing the complexity of large data sets and offers better interpretation (Yücel and Sultanoğlu, 2013). Until now, no research study concerning the properties of honey samples from semi-arid regions was reported.

The aims of this work therefore is firstly: to characterize the honeys from different semi-arid regions in Algeria according to their physicochemical properties $(\mathrm{pH}$, free acidity, moisture content, electrical conductivity, ash content, glucose, fructose, sucrose, turanose and maltose) and the major elements (Ca, $\mathrm{K}, \mathrm{Mg}$ and $\mathrm{Na}$ ). Secondly: is to apply multivariate statistical techniques such as PCA and CA to differentiate the three honey types multifloral, sulla (Hedysarum coronarium) and luzerne (Medicago sativa) in the semi-arid regions.

\section{MATERIALS AND METHODS}

\section{Honey samples}

Twenty honey samples of Apis mellifera intermissa produced in various semi-arid regions of northeastern Algeria (Table 1) and (Fig. 1) were collected from beekeepers. All samples were collected in airtight plastic containers and then they have been stored in a refrigerator at $4-5{ }^{\circ} \mathrm{C}$ until analysis. All the analyses were carried out at least in duplicate.

\section{Physicochemical characteristics}

$\mathrm{pH}$ of honey samples were analyzed according to methods previously reported for $\mathrm{pH}$, free acidity, moisture content,
Table 1: Geographical origins of honey samples from Algerian semi-arid regions

\begin{tabular}{llll}
\hline Sample & Honey type & States & $\begin{array}{l}\text { Geographic } \\
\text { origin }\end{array}$ \\
\hline H1 & Multifloral & Setif & Ain- Azzele \\
H2 & luzerne (Medicago sativa) & Mila & Telaguema \\
H3 & Multifloral & & Mila \\
H4 & Multifloral & & Mila \\
H5 & Sulla (Hedysarum coronarium) & Khenchela & Bouhmema \\
H6 & Multifloral & & Chachare \\
H7 & Sulla (Hedysarum coronarium) & Batna & Mafa Ain \\
& & & Touta \\
H8 & Multifloral & Hidoussa \\
H9 & Sulla (Hedysarum coronarium) & Oum- El- & Kasr-El-Sbihi \\
& & Bouaghi & \\
H10 & Sulla (Hedysarum coronarium) & & Ain-El -baida \\
H11 & Multifloral & & Meskianna \\
H12 & Sulla (Hedysarum coronarium) & & Ain-mlila \\
H13 & Multifloral & Tebessa & Oinza \\
H14 & Multifloral & & Ain Zargua \\
H15 & Multifloral & & Boukdra \\
H16 & Multifloral & & Yokous \\
H17 & Multifloral & Limit Tebessa- \\
& Sulla (Hedysarum coronarium) & & Tunisie \\
H18 & Mulin Zarga \\
H19 & Multifloral & Morset \\
H20 & Multifloral & Tebessa \\
\hline & & & \\
\hline
\end{tabular}

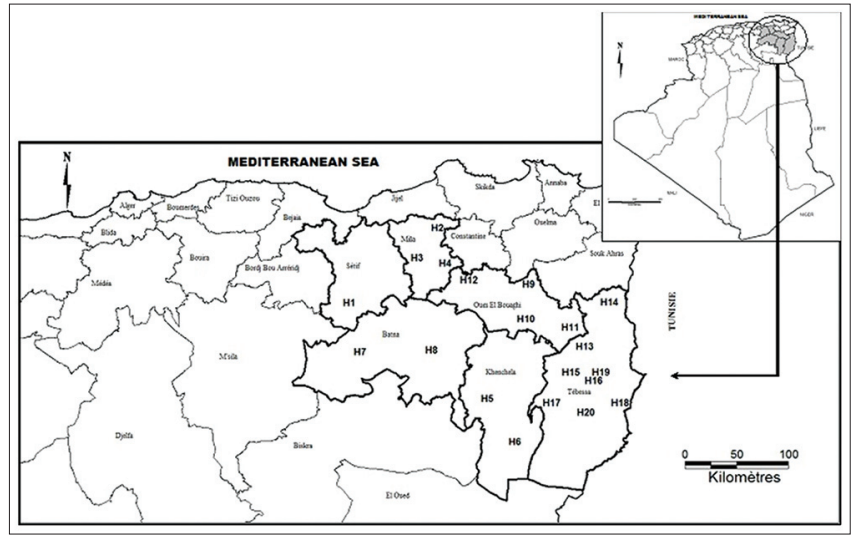

Fig 1. Geographical origin of the honey samples from different semiarid regions (North-East Algeria).

electrical conductivity, ash and sugar determination (Bogdanov et al., 1997).

Free acidity was determined using the AT-510 Automatic potentiometric titrator (Kyoto, Japan) and the combined electrode Flustrode Hamilton. $\mathrm{pH}$ was determined by using glass electrode after calibration with standard buffer solution $\mathrm{pH} 4$ and 10.

Moisture content was determined by refractometry, measuring the refractive index (RI). All measurements were performed at $20^{\circ} \mathrm{C}$ in a digital RX-5000 refractometer (ATAGO, USA). Water content $(\mathrm{g} / 100 \mathrm{~g})$ was then obtained from the Chataway table. 
Electrical conductivity was measured at $20{ }^{\circ} \mathrm{C}$ in a $20 \%$ $(\mathrm{w} / \mathrm{v})$ solution (dry matter basis) in deionised water with specific electrical conductivity $\mathrm{mS} / \mathrm{cm}$ using a conductivity using conductivity meter WTW INOLAB Level 2 c (Werkstätten, GmbH, Germany).

Ash content was indirectly determined using the measured electrical conductivity by applying the following equation: $y=0.551 x-0.089$, were: $=y$ ash value; $x=$ electrical conductivity in $\mathrm{mS} / \mathrm{cm}$ at $20{ }^{\circ} \mathrm{C}$ (Feás et al., 2010).

Sugar content was determined by a HPLC Agilent 1200 (Ramsey, Minnesota, USA) fitted with a refractive index detector (HPLC-RI) at $30^{\circ} \mathrm{C}$ and analytical stainless-steel column in polar aminopropylsilane $\left(-\mathrm{NH}_{2}\right)$. In a $100 \mathrm{ml}$ volumetric flask, containing $25 \mathrm{ml}$ of methanol, $5 \mathrm{~g}$ of honey dissolved in $40 \mathrm{ml}$ water were transferred and filled up with water. The solution was centrifuged for 10 minutes at 3500 tours, then it collected in sample vials and injected $(10 \mu \mathrm{l})$ into the HPLC. The mobile phase: Acetonitrile $80 \%$ and $20 \%$ water at a flow rate of $1.3 \mathrm{ml} / \mathrm{min}$. Authenticated standards of fructose, glucose, sucrose, turanose and maltose were used to quantify the amount of sugars in the sample. Results were expressed as gram sugar per $100 \mathrm{~g}$ of honey.

\section{Mineral contents}

Wet digestion method is applied for the digestion of the honey samples. $1 \mathrm{~g}$ from real samples was digested with a mixture of $8 \mathrm{ml} \mathrm{HNO}_{3}(65 \%)$ and $4 \mathrm{ml} \mathrm{H}_{2} \mathrm{O}_{2}(30 \%)$. The mixture was heated up to $150{ }^{\circ} \mathrm{C}$ on the hot plate. After evaporation to near dryness, $5 \mathrm{ml}$ of high purity deionized water (resistivity $18.2 \mathrm{M} \Omega / \mathrm{cm}$ ) was added to the sample and well mixed. The solution was filtered and diluted to $10 \mathrm{ml}$ with de-ionized water. The same procedure was applied for a blank. Horiba-Jobin Yvon Model Ultima 2 (France) inductively coupled plasma atomic emission spectrometry (ICP-AES) was used to determine $\mathrm{Ca}, \mathrm{K}, \mathrm{Mg}$ and $\mathrm{Na}$.

\section{Statistical analysis}

The statistical package (Statistica 8.0 software for windows from Statsoft) was used to establish the difference between the honey samples by mean of their physicochemical parameters and major element. Results are expressed as mean values, range of values and standard deviation (SD). For all honeys, correlation analysis was performed between the parameters. Chemometric techniques are used to classify honeys according to their origin in the physicochemical parameters and major elements data.

\section{RESULTS AND DISCUSSION}

\section{Physicochemical characteristics}

The obtained results of several physicochemical parameters and major elements of three honey types multifloral, sulla
(Hedysarum coronarium) and luzerne (Medicago sativa) of the semi-arid Algerian regions are presented in Table 2.

The $\mathrm{pH}$ average of multifloral honeys was $4.09 \pm 0.25$ (3.69 - 4.48), while sulla and luzerne honeys were $3.95 \pm 0.17(3.76-4.14)$ and 3.78 respectively. All honeys of semi-arid Algerian regions are acidic and these are the typical $\mathrm{pH}$ values in floral honeys. The $\mathrm{pH}$ of honey is reported to be affected by the conditions during extraction and storage, because acidity can influence the texture, stability, and shelf life of honey (Terrab et al., 2004). The low $\mathrm{pH}$ of honey inhibits the presence and growth of microorganisms (Feás et al., 2010). The $\mathrm{pH}$ values of the semi-arid Algerian honey were within the $\mathrm{pH}$ range of 3.40 to 6.23 reported by Makhloufi et al. (2010) for Algerian honey and 3.33 to 4.6 for northeast Algerian honey reported by Amri, and Ladjama (2013).

Free acidity of honey samples from the multifloral, sulla and luzerne were $13.99 \pm 4.96 \mathrm{meq} / \mathrm{kg}$ $(6.80-20.03 \mathrm{meq} / \mathrm{kg}), 13.51 \pm 3.68 \mathrm{meq} / \mathrm{kg}(7.86-$ $18.99 \mathrm{meq} / \mathrm{kg}$ ) and $19.02 \mathrm{meq} / \mathrm{kg}$ respectively. All samples of semi-arid Algerian regions felt within the maximum limit for free acid of $50 \mathrm{meq} / \mathrm{kg}$ (Council of the European Union, 2002). The acidity of honey is due to the presence of organic acids; especially the gluconic acid and inorganic ions such as phosphates and chlorides (Nandaa et al., 2003), and their measurements are useful for the evaluation of honey fermentation (Ruoff et al., 2007). According to Belay et al. (2013), the mean free acidity content of the Harenna forest honey samples was $34.57 \pm 4.80 \mathrm{meq} / \mathrm{kg}$ and ranging from 25.49 to $48.81 \mathrm{meq} / \mathrm{kg}$. The free acidity of Algerian semi-arid honey samples was lower than the results reported by Belay et al. (2013). Hence, the lower value of acidity indicates the absence of undesirable fermentations (Kucuk et al., 2007).

The moisture content measurement of honey is the most important for the assessment of ripeness and shelf life (Ruoff et al., 2007). The moisture content of multifloral honey samples in semi-arid Algerian regions ranged from 14.00 to $17.15 \mathrm{~g} / 100 \mathrm{~g}$, with a mean value of $15.64 \pm$ $1.04 \mathrm{~g} / 100 \mathrm{~g}$, but that of sulla honey samples ranged from 13.18 to $16.19 \mathrm{~g} / 100 \mathrm{~g}$ (mean $15.14 \pm 0.80 \mathrm{~g} / 100 \mathrm{~g}$ ), while the average moisture content of Luzerne honey is $16.43 \mathrm{~g} / 100 \mathrm{~g}$. Such values were smaller than 10.6 to $17.8 \mathrm{~g} / 100 \mathrm{~g}$ reported by Ajlouni and Sujirapinyokul (2010) of Australian honeys. However, Chefrour et al. (2009) stated the moisture content of honey, which was ranging from 16.4 to $21.4 \mathrm{~g} / 100 \mathrm{~g}$, from North-east Algeria. Compared with this result, the semi-arid Algerian honey contained lower moisture of $15.75 \pm 1.09 \mathrm{~g} / 100 \mathrm{~g}$. The mean moisture content of honey, in this study, was also lower than the maximum limit for moisture content 
Table 2: Physicochemical parameters of honey samples from Algerian semi-arid regions (values are mean \pm SD and range)

\begin{tabular}{|c|c|c|c|c|c|}
\hline \multirow[t]{2}{*}{ Variables } & \multirow[t]{2}{*}{ Units } & \multirow[t]{2}{*}{ Statistics } & \multicolumn{3}{|c|}{ Honey type } \\
\hline & & & $\begin{array}{l}\text { Multifloral } \\
n=13\end{array}$ & $\begin{array}{l}\text { Sulla (Hedysarum coronarium) } \\
\mathrm{n}=6\end{array}$ & $\begin{array}{c}\text { luzerne (Medicago sativa) } \\
n=1\end{array}$ \\
\hline $\mathrm{pH}$ & $\mathrm{pH}$ units & $\begin{array}{l}\text { Mean } \pm S D \\
\text { Range }\end{array}$ & $\begin{array}{l}4.09 \pm 0.25 \\
3.69-4.48\end{array}$ & $\begin{array}{l}3.95 \pm 0.17 \\
3.76-4.14\end{array}$ & 3.78 \\
\hline Free acidity & $\mathrm{meq} / \mathrm{kg}$ & $\begin{array}{l}\text { Mean } \pm S D \\
\text { Range }\end{array}$ & $\begin{array}{l}13.99 \pm 4.96 \\
6.80-20.03\end{array}$ & $\begin{array}{l}13.51 \pm 3.68 \\
7.86-18.99\end{array}$ & 19.02 \\
\hline Moisture & $\mathrm{g} / 100 \mathrm{~g}$ & $\begin{array}{l}\text { Mean } \pm S D \\
\text { Range }\end{array}$ & $\begin{array}{c}15.64 \pm 1.04 \\
14.00-17.15\end{array}$ & $\begin{array}{c}15.14 \pm 0.80 \\
13.81-16.19\end{array}$ & 16.43 \\
\hline Electrical conductivity & $\mathrm{mS} / \mathrm{cm}$ & $\begin{array}{l}\text { Mean } \pm S D \\
\text { Range }\end{array}$ & $\begin{array}{l}0.38 \pm 0.18 \\
0.13-0.67\end{array}$ & $\begin{array}{l}0.28 \pm 0.09 \\
0.12-0.35\end{array}$ & 0.76 \\
\hline Ash & $\mathrm{g} / 100 \mathrm{~g}$ & $\begin{array}{l}\text { Mean } \pm S D \\
\text { Range }\end{array}$ & $\begin{array}{l}0.122 \pm 0.1 \\
0.005-0.3\end{array}$ & $\begin{array}{l}0.068 \pm 0.04 \\
0.005-0.10\end{array}$ & 0.331 \\
\hline Fructose & $\mathrm{g} / 100 \mathrm{~g}$ & $\begin{array}{l}\text { Mean } \pm S D \\
\text { Range }\end{array}$ & $\begin{array}{l}40.14 \pm 3.84 \\
28.49-43.34\end{array}$ & $\begin{array}{l}39.10 \pm 4.83 \\
32.82-44.05\end{array}$ & 37.78 \\
\hline Glucose & $\mathrm{g} / 100 \mathrm{~g}$ & $\begin{array}{l}\text { Mean } \pm S D \\
\text { Range }\end{array}$ & $\begin{array}{l}30.57 \pm 3.05 \\
21.33-33.80\end{array}$ & $\begin{array}{l}29.11 \pm 4.02 \\
23.82-32.46\end{array}$ & 27.50 \\
\hline$M(F+G)$ & $\mathrm{g} / 100 \mathrm{~g}$ & $\begin{array}{l}\text { Mean } \pm S D \\
\text { Range }\end{array}$ & $\begin{array}{l}70.71 \pm 6.79 \\
49.82-77.14\end{array}$ & $\begin{array}{l}68.21 \pm 8.70 \\
56.87-76.51\end{array}$ & 65.28 \\
\hline$(\mathrm{F} / \mathrm{G})$ ratio & $\mathrm{g} / 100 \mathrm{~g}$ & $\begin{array}{l}\text { Mean } \pm S D \\
\text { Range }\end{array}$ & $\begin{array}{l}1.31 \pm 0.04 \\
1.27-1.42\end{array}$ & $\begin{array}{l}1.35 \pm 0.07 \\
1.26-1.43\end{array}$ & 1.37 \\
\hline Sucrose & $\mathrm{g} / 100 \mathrm{~g}$ & $\begin{array}{l}\text { Mean } \pm S D \\
\text { Range }\end{array}$ & $\begin{array}{l}0.91 \pm 1.56 \\
0.00-4.36\end{array}$ & $\begin{array}{l}0.75 \pm 0.87 \\
0.00-2.01\end{array}$ & 4.22 \\
\hline Turanose & $\mathrm{g} / 100 \mathrm{~g}$ & $\begin{array}{l}\text { Mean } \pm S D \\
\text { Range }\end{array}$ & $\begin{array}{l}1.47 \pm 0.65 \\
1.01-2.84\end{array}$ & $\begin{array}{l}1.44 \pm 0.37 \\
1.06-1.97\end{array}$ & 0.90 \\
\hline Maltose & $\mathrm{g} / 100 \mathrm{~g}$ & $\begin{array}{l}\text { Mean } \pm S D \\
\text { Range }\end{array}$ & $\begin{array}{l}3.07 \pm 1.50 \\
0.95-5.24\end{array}$ & $\begin{array}{l}2.87 \pm 0.87 \\
2.01-3.94\end{array}$ & 1.65 \\
\hline $\mathrm{Ca}$ & $\mathrm{mg} / \mathrm{kg}$ & $\begin{array}{l}\text { Mean } \pm S D \\
\text { Range }\end{array}$ & $\begin{array}{c}17.47 \pm 5.58 \\
13.20-33.51\end{array}$ & $\begin{array}{c}14.04 \pm 3.79 \\
10.65-21.37\end{array}$ & 14.38 \\
\hline K & $\mathrm{mg} / \mathrm{kg}$ & $\begin{array}{l}\text { Mean } \pm S D \\
\text { Range }\end{array}$ & $\begin{array}{c}57.85 \pm 35.86 \\
11.58-124.75\end{array}$ & $\begin{array}{c}34.06 \pm 15.84 \\
7.55-51.98\end{array}$ & 107.30 \\
\hline $\mathrm{Mg}$ & $\mathrm{mg} / \mathrm{kg}$ & $\begin{array}{l}\text { Mean } \pm S D \\
\text { Range }\end{array}$ & $\begin{array}{l}2.10 \pm 1.23 \\
0.42-4.70\end{array}$ & $\begin{array}{l}2.04 \pm 0.37 \\
1.41-2.53\end{array}$ & 1.15 \\
\hline $\mathrm{Na}$ & $\mathrm{mg} / \mathrm{kg}$ & $\begin{array}{l}\text { Mean } \pm S D \\
\text { Range }\end{array}$ & $\begin{array}{l}3.06 \pm 1.44 \\
1.25-5.91\end{array}$ & $\begin{array}{l}2.34 \pm 0.44 \\
1.49-2.74\end{array}$ & 5.37 \\
\hline
\end{tabular}

F: Fructose, G: Glucose, n: Number of samples, M: Mean, SD: Standard deviation

set by the Council of the European Union of $20 \mathrm{~g} / 100 \mathrm{~g}$ (Council of the European Union, 2002). Thus, the moisture content in honey is influenced by geographical, climatic and seasonal conditions (Ajlouni and Sujirapinyokul, 2010). Moreover, water content is strictly related to the degree of maturity in the hive, the botanical origin of the honey sample, the harvesting techniques and the extraction from the comb in relation to the ripening process made by bees (Finola et al., 2007).

The electrical conductivity of honey can be explained by taking into account the ash and acid content of the sample, which reflects the presence of ions and organic acids; thus the higher their content, the higher the resulting conductivity (Feás et al., 2010).

The average electrical conductivity for multifloral, sulla and luzerne honey samples in semi-arid Algerian regions were $0.38 \pm 0.18 \mathrm{mS} / \mathrm{cm}(0.13-0.67 \mathrm{mS} / \mathrm{cm}), 0.28 \pm 0.09 \mathrm{mS} / \mathrm{cm}$ $(0.12-0.35 \mathrm{mS} / \mathrm{cm})$ and $0.76 \mathrm{mS} / \mathrm{cm}$ respectively. According to the Council of the European Union Council of the
European Union (2002), nectar honey should have conductivity values below $0.8 \mathrm{mS} / \mathrm{cm}$, higher conductivity values are considered as belonging to honeydew or to the mixtures of honeydew and nectar. Therefore, all samples had conductivity measurements below $0.8 \mathrm{mS} / \mathrm{cm}$; this indicates that honeys collected for this study were of floral origin.

Ash content of honey samples from multifloral and sulla in this region ranged from 0.005 to $0.30 \mathrm{~g} / 100 \mathrm{~g}$ (mean $0.122 \pm$ $0.1 \mathrm{~g} / 100 \mathrm{~g}$ ) and 0.005 to $0.10 \mathrm{~g} / 100 \mathrm{~g}$ (mean $0.068 \pm 0.04$ $\mathrm{g} / 100 \mathrm{~g}$ ), respectively and the average Ash content of luzerne honey is $0.331 \mathrm{~g} / 100 \mathrm{~g}$. The results obtained are within the limit allowed for honeys $0.6 \mathrm{~g} / 100 \mathrm{~g}$ (Bogdanov et al., 1999).

The difference in ash content across location was expected to happen due to the botanical origin of honey, concentration of minerals found in the nectar on different apiaries and to the variability of soil type (Belay et al., 2013).

Sugars composition depends highly on the types of flowers used by the bees, regional and climatic conditions (Mateo 
and Bosch-Reig, 1998). Two monosaccharides (fructose and glucose) and three disaccharides (maltose turanose, and sucrose) concentrations of the honey samples are identified and quantified in three honey types analyzed. Fructose and glucose were the major carbohydrates of all honey types. The proportions of fructose and glucose are determined by the composition of the plant secretion (Molan, 1996).

Fructose is the major sugar in three honey types followed by glucose, maltose, turanose and sucrose. Fructose concentrations of multifloral, sulla and luzerne honey samples in semi-arid regions ranged from 28.49 to $43.34 \mathrm{~g} / 100 \mathrm{~g}$ (mean $40.14 \pm 3.84 \mathrm{~g} / 100 \mathrm{~g}$ ), 32.82 to 44.05 $\mathrm{g} / 100 \mathrm{~g}$ (mean $39.10 \pm 4.83 \mathrm{~g} / 100 \mathrm{~g}$ ) and $37.78 \mathrm{~g} / 100 \mathrm{~g}$ respectively. Glucose concentrations of honey samples from multifloral and sulla ranged from 21.33 to $33.80 \mathrm{~g} / 100 \mathrm{~g}$ (mean $30.57 \pm 3.05 \mathrm{~g} / 100 \mathrm{~g}$ ) and 23.82 to $32.46 \mathrm{~g} / 100 \mathrm{~g}$ (mean $29.11 \pm 4.02 \mathrm{~g} / 100 \mathrm{~g}$ ), respectively and the average glucose concentrations of luzerne honey is $27.50 \mathrm{~g} / 100 \mathrm{~g}$. Fructose is the most important sugar quantitatively followed by glucose in three honey types. These results are in agreement with those of Ouchemoukh et al. (2010) concerning the Algerian honeys. Except for two samples H17 and H5 (mean $49.82 \pm$ $0.63 \mathrm{~g} / 100 \mathrm{~g}$ and $56.87 \pm 0.37 \mathrm{~g} / 100 \mathrm{~g}$ respectively). All the honeys presented a value of both glucose and fructose $(65.20-77.14 \mathrm{~g} / 100 \mathrm{~g})$ higher than $60 \mathrm{~g} / 100 \mathrm{~g}$, which was in accordance with the legislations of the Council of the European Union (2002). The ratio of fructose to glucose of three honey types is between 1.26 and $1.43 \mathrm{~g} / 100 \mathrm{~g}$, indicating the honey samples originating from different floral sources. The fructose/glucose of semi-arid region honeys is similar with that of the values reported by Ouchemoukh et al. (2010) concerning the Algerian honeys. Hence, honey with ratio fructose/glucose exceeds $1.5 \mathrm{~g} / 100$ $\mathrm{g}$ is always in liquid physical state (Ouchemoukh et al., 2010). In relation to the disaccharides, maltose is the major disaccharide is present in all samples. Maltose concentration ranged between 0.95 and $5.24 \mathrm{~g} / 100 \mathrm{~g}$ (mean $3.07 \pm 1.50$ $\mathrm{g} / 100 \mathrm{~g})$ for multifloral. The value obtained is higher than the value found by Ouchemoukh et al. (2010) for Algerian multifloral honeys. The average maltose concentration for sulla honey samples in semi-arid Algerian regions is $2.87 \pm 0.87 \mathrm{~g} / 100 \mathrm{~g}$. This value is similar than sulla honey reported by Ouchemoukh et al. (2010). The value obtained for Luzerne honey $(1.65 \mathrm{~g} / 100 \mathrm{~g})$ is similar than the value found by Ouchemoukh et al. (2010) for Algerian melilotus honey. Turanose is present in three honey types multifloral, sulla and Luzerne. The averages are $1.47 \pm 0.65 \mathrm{~g} / 100 \mathrm{~g}$, $1.44 \pm 0.37 \mathrm{~g} / 100 \mathrm{~g}$ and $0.90 \mathrm{~g} / 100 \mathrm{~g}$ respectively. The value obtained for sulla honey is higher than sulla honey reported by Ouchemoukh et al. (2010). Sucrose content in honeys can be increased if the beekeeper has over-fed the bees with sugar during spring, therefore is an important sugar from the legislative point of view (Anklam, 1998). Sucrose content ranged between 0.00 and $4.36 \mathrm{~g} / 100 \mathrm{~g}$; therefore, all three honey types analyzed in semi-arid Algerian regions here had a sucrose content lower than $5 \mathrm{~g} / 100 \mathrm{~g}$, which is generally taken as the maximum limit value for honeys allowed by European Community Directive (Council of the European Union, 2002).

\section{Mineral contents}

The major elements (Ca, K, Mg and $\mathrm{Na}$ ) content determined in semi-arid honey samples are quantified. Mineral content of honey is heavily dependent on the type of flower used by bees for nectar (Nanda et al., 2003). Potassium was, quantitatively, the most abundant and the major elements present in all three honey types. The average content of multifloral is $51.29 \mathrm{mg} / \mathrm{kg}$ and it showed a concentration from 11.58 to $124.75 \mathrm{mg} / \mathrm{kg}$, while sulla and luzerne honeys were $34.06 \pm 15.84 \mathrm{mg} / \mathrm{kg}(7.55-51.98 \mathrm{mg} / \mathrm{kg})$ and $107.30 \mathrm{mg} / \mathrm{kg}$ respectively. However, in this work the average $\mathrm{K}$ value was lower when compared with other studies; $3140 \mathrm{mg} / \mathrm{kg}$ (Chudzinska, and Baralkiewicz, 2010), $1205 \mathrm{mg} / \mathrm{kg}$ (Stankovska et al., 2008), $930 \mathrm{mg} / \mathrm{kg}$ (Freitas et al., 2006) and $406 \mathrm{mg} / \mathrm{kg}$ (Almeida-Silva et al., 2011).

The other major elements calcium, sodium and magnesium were present in moderate amounts in three honey types. The average concentrations of $\mathrm{Ca}, \mathrm{Na}$ and $\mathrm{Mg}$ from multifloral honey in semi-arid Algerian regions ranged between $13.20-33.51 \mathrm{mg} / \mathrm{kg}$; $1.25-5.91 \mathrm{mg} / \mathrm{kg} ; 0.42-4.70 \mathrm{mg} / \mathrm{kg}$, respectively (mean values are $17.47 \pm 5.58 \mathrm{mg} / \mathrm{kg} ; 3.06 \pm 1.44 \mathrm{mg} / \mathrm{kg}$; $2.10 \pm 1.23 \mathrm{mg} / \mathrm{kg}$, respectively). The mean values for two types of monofloral (sulla and Luzerne) honeys studied were $3.95 \pm 0.17 \mathrm{mg} / \mathrm{kg}(3.76-4.14 \mathrm{mg} / \mathrm{kg})$ and $3.78 \mathrm{mg} / \mathrm{kg}$ respectively. The levels of these elements are lower according to the study concerning honey mineral contents (Terrab et al., 2004; Hernandez et al., 2005; Silva et al., 2009; Yücel, and Sultanoğlu, 2013). Generally, the concentration of $\mathrm{Mg}$ is tenfold lower according to the study concerning honey mineral content (Terrab et al., 2004; Hernandez et al., 2005).

\section{Statistical analysis}

The data in Table 3 shows that the correlations are significant at $p<0.05$. In addition, a strong positive correlation was reported between fructose and glucose $(r=0.94)$, electrical conductivity and potassium $(r=0.95)$, free acidity and electrical conductivity $(r=0.82), \mathrm{Ca}$ and $\mathrm{Mg}(r=0.81)$. Nasiruddin Khan et al. (2006) have showed similar correlations between total ash content of honey and electrical conductivity.

The analysis of principal component was applied to the matrix of the correlations obtained starting from the standardized data of 16 variables, measured to 20 honey 
Table 3: Matrix correlations between different variables of honey samples from Algerian semi-arid regions

\begin{tabular}{|c|c|c|c|c|c|c|c|c|c|c|c|c|c|c|}
\hline Variables & $\mathrm{pH}$ & $\begin{array}{l}\text { Free } \\
\text { acidity }\end{array}$ & Moisture & $\begin{array}{c}\text { Electrical } \\
\text { conductivity }\end{array}$ & Fructose & Glucose & Saccharose & Turanose & Maltose & $\mathrm{Ca}$ & $K$ & $\mathrm{Mg}$ & $\mathrm{Na}$ & Ash \\
\hline $\mathrm{pH}$ & 1 & & & & & & & & & & & & & \\
\hline Free acidity & -0.19 & 1 & & & & & & & & & & & & \\
\hline Moisture & $-0.52^{*}$ & 0.38 & 1 & & & & & & & & & & & \\
\hline $\begin{array}{l}\text { Electrical } \\
\text { conductivity }\end{array}$ & 0.05 & $0.82^{* * *}$ & 0.30 & 1 & & & & & & & & & & \\
\hline Fructose & -0.07 & 0.41 & 0.25 & 0.20 & 1 & & & & & & & & & \\
\hline Glucose & -0.07 & 0.42 & 0.35 & 0.22 & $0.94^{\star \star \star}$ & 1 & & & & & & & & \\
\hline Saccharose & -0.44 & 0.20 & 0.44 & 0.38 & -0.13 & -0.08 & 1 & & & & & & & \\
\hline Turanose & $0.70^{\star \star \star}$ & 0.07 & -0.31 & 0.15 & 0.21 & 0.26 & -0.42 & 1 & & & & & & \\
\hline Maltose & $0.72^{\star \star \star}$ & 0.02 & -0.22 & 0.09 & 0.26 & 0.30 & -0.27 & $0.80^{* * *}$ & 1 & & & & & \\
\hline $\mathrm{Ca}$ & $0.46^{*}$ & 0.17 & -0.23 & 0.26 & 0.01 & -0.04 & -0.18 & 0.31 & 0.42 & 1 & & & & \\
\hline K & 0.27 & $0.76^{\star * *}$ & 0.20 & $0.95^{\star \star \star}$ & 0.17 & 0.21 & 0.29 & 0.29 & 0.32 & 0.35 & 1 & & & \\
\hline $\mathrm{Mg}$ & 0.35 & $0.55^{\star}$ & -0.16 & 0.41 & 0.12 & 0.16 & -0.29 & 0.42 & $0.47^{*}$ & 0.40 & $0.56^{*}$ & 1 & & \\
\hline $\mathrm{Na}$ & 0.17 & $0.49^{*}$ & 0.33 & $0.76^{\star \star *}$ & 0.10 & 0.17 & 0.38 & 0.42 & 0.14 & 0.07 & $0.69^{* * *}$ & 0.07 & 1 & \\
\hline Ash & 0.03 & $0.81^{* * *}$ & 0.32 & $1.00^{\star \star *}$ & 0.18 & 0.21 & 0.40 & 0.14 & 0.08 & 0.25 & $0.95^{\star * *}$ & 0.41 & $0.76^{\star * *}$ & 1 \\
\hline
\end{tabular}

$\left(^{\star}\right)$ correlations are significant at $\mathrm{P}<0.05,\left(^{* \star *}\right)$ correlations are significant at $\mathrm{P}<0.001$

Table 4: (a) Eigenvalues and variances of principle components, (b) Loadings of the variables for the four principal components

\begin{tabular}{|c|c|c|c|c|c|}
\hline (a) Number of PC & Eigenvalı & lue & Variance & & Cumulative $\%$ \\
\hline 1 & 5.51 & & 34.47 & & 34.47 \\
\hline 2 & 3.47 & & 21.67 & & 56.14 \\
\hline 3 & 2.79 & & 17.42 & & 73.56 \\
\hline 4 & 1.31 & & 8.18 & & 81.74 \\
\hline 5 & 0.94 & & 5.85 & & 87.60 \\
\hline 6 & 0.69 & & 4.30 & & 91.89 \\
\hline 7 & 0.45 & & 2.82 & & 94.72 \\
\hline 8 & 0.39 & & 2.42 & & 97.14 \\
\hline 9 & 0.27 & & 1.66 & & 98.79 \\
\hline 10 & 0.10 & & 0.65 & & 99.44 \\
\hline 11 & 0.07 & & 0.44 & & 99.88 \\
\hline 12 & 0.01 & & 0.07 & & 99.95 \\
\hline 13 & 0.01 & & 0.04 & & 99.99 \\
\hline 14 & 0.00 & & 0.00 & & 100.00 \\
\hline 15 & 0.00 & & 0.00 & & 100.00 \\
\hline (b) Variable & PC1 & PC2 & PC3 & PC4 & $\begin{array}{c}\text { Corr }^{2}(\%) \\
(\text { PC1+PC2) }\end{array}$ \\
\hline $\mathrm{pH}$ & -0.196 & 0.840 & 0.271 & 0.202 & 74.45 \\
\hline Free acidity & -0.825 & -0.291 & 0.049 & -0.326 & 76.58 \\
\hline Moisture & -0.329 & -0.673 & -0.264 & 0.243 & 56.12 \\
\hline Electrical conductivity & -0.871 & -0.266 & 0.370 & -0.085 & 82.93 \\
\hline Ash & -0.861 & -0.284 & 0.380 & -0.087 & 82.15 \\
\hline Fructose & -0.529 & 0.044 & -0.778 & -0.222 & 28.22 \\
\hline Glucose & -0.594 & 0.018 & -0.795 & 0.024 & 35.34 \\
\hline$M(F+G)$ & -0.568 & 0.033 & -0.798 & -0.112 & 32.34 \\
\hline$(\mathrm{F} / \mathrm{G})$ ratio & 0.358 & 0.038 & 0.264 & -0.628 & 12.96 \\
\hline Saccharose & -0.171 & -0.713 & 0.252 & 0.238 & 53.84 \\
\hline Turanose & -0.438 & 0.743 & 0.003 & 0.339 & 74.46 \\
\hline Maltose & -0.416 & 0.750 & -0.067 & 0.246 & 73.60 \\
\hline $\mathrm{Ca}$ & -0.341 & 0.476 & 0.232 & -0.362 & 34.31 \\
\hline K & -0.889 & -0.051 & 0.402 & -0.053 & 79.28 \\
\hline $\mathrm{Mg}$ & -0.556 & 0.421 & 0.184 & -0.308 & 48.65 \\
\hline $\mathrm{Na}$ & -0.703 & -0.190 & 0.316 & 0.414 & 53.00 \\
\hline
\end{tabular}

F: Fructose, G: Glucose, M: Mean, Corr: *correlation sample in order to determine the differences between the types of honey. The eigenvalues and percentage variance explained by each principal component are shown in Table 4a. The first four components were chosen to examine the dataset and they explained $81.74 \%$ of the total variance, which was showed that the honey types were well distinguished by their physicochemical parameters. The first principal component (PC1) represented 34.47\% and the next principal components were $21.67 \%, 17.42 \%$ and $8.18 \%$ respectively. The loadings of the variables for the principal components (PC1 - PC4) are showed in Table 4b. Thus, these four axes or aggregative indexes as well as possible summarize the information brought for the 16 variables. The first axes which only contains with him $34.47 \%$ of the information brought by the whole of the initial variables was strongly associated with the value of free acidity, electrical conductivity, Ash, $\mathrm{K}$ and $\mathrm{Na}$. The dominant variables in the second axis were $\mathrm{pH}$, saccharose, turanose and maltose. While the third axis is made up by the following variables: fructose, glucose and $M(F+G)$. Lastly, the fourth axis is formed only by variable (F/G) ratio. The first two principal components (PC1 and PC2) related to the most physicochemical parameters $(\mathrm{pH}$, free acidity, electrical conductivity, ash, saccharose, turanose, maltose, $\mathrm{K}$ and $\mathrm{Na}$ ). The scores and loadings plots of the first two principal components for the discrimination of honey samples according to their botanical origin shown in Fig. 2. Thus, examination of Fig. 2a allows to note that the variables: $(\mathrm{F} / \mathrm{G})$ ratio, fructose, glucose, $\mathrm{M}(\mathrm{F}+\mathrm{G}), \mathrm{Ca}$ and $\mathrm{Mg}$ have low lengths vectors, thus indicating low correlations and therefore an inadequate consideration of these variables by the set of two axes. Their squared correlations range from $12.96 \%$ to 48.65 $\%$. The other variables such as $\mathrm{pH}$, free acidity, moisture, electrical conductivity, ash, saccharose, turanose, maltose, 
$\mathrm{K}$ and $\mathrm{Na}$ have close correlation circle and are therefore better represented. What is normal because their square correlations vary from $53.00 \%$ to $82.93 \%$. In addition, the variables that have vectors close from each other indicating a strong correlation between these two variables. Fig. $2 \mathrm{~b}$ and Table 5 show that the samples H1, H2, H4, H5, H13, $\mathrm{H} 17, \mathrm{H} 18, \mathrm{H} 19$, and $\mathrm{H} 20$ are well represented by the axes 1 and 2. These samples have values of in the factorial plan 1-2 very high vary from $55.37 \%$ to $91.27 \%$. The other samples are close to the origin and have weak values of the square cosine, which vary between $4.15 \%$ and 46.61 $\%$. They considered little by the axis 1 and 2 .

Cluster analysis is a statistical method was performed to classify honeys according to their physicochemical properties and the major elements. Complete linkage cluster analysis was applied to the data matrix, where the Euclidean distance was used to calculate the sample similarities and a hierarchical agglomerative procedure was employed to establish clusters. The results obtained are shown as a dendogram in Fig. 3. Generally, at a similarity level of $80 \%$, the samples clustered into two groups corresponding to two botanical origins. From the left, the first cluster was formed by mixture of two types multifloral and luzerne, the second cluster was composed of mixture of two types multifloral and sulla (Fig. 3 a). These results shows that the three honey types multifloral, sulla (Hedysarum coronarium) and luzerne (Medicago sativa) of the semi-arid Algerian regions are not well separated by their physicochemical parameters and major elements. In addition, the clusters were divided into subgroups. These subgroups connected

\begin{tabular}{lccc}
$\begin{array}{l}\text { Table 5: Cosine squares (\%) based on correlations of the first } \\
\text { two components (PC1+PC2) }\end{array}$ \\
\hline Samples & \multicolumn{3}{l}{ Cos $^{2}$ (\%) } \\
\cline { 2 - 4 } & PC1 & PC2 & (PC1+PC2) \\
H1 & 37.33 & 20.44 & 57.77 \\
H2 & 16.62 & 50.50 & 67.12 \\
H3 & 18.75 & 0.32 & 19.07 \\
H4 & 4.03 & 54.56 & 58.59 \\
H5 & 78.13 & 1.46 & 79.58 \\
H6 & 29.05 & 17.55 & 46.61 \\
H7 & 1.00 & 12.24 & 13.24 \\
H8 & 1.69 & 2.67 & 4.36 \\
H9 & 36.98 & 2.87 & 39.85 \\
H10 & 4.25 & 12.83 & 17.09 \\
H11 & 0.08 & 24.42 & 24.50 \\
H12 & 2.72 & 1.43 & 4.15 \\
H13 & 33.16 & 58.11 & 91.27 \\
H14 & 31.26 & 1.16 & 32.42 \\
H15 & 15.77 & 12.10 & 27.88 \\
H16 & 5.11 & 28.95 & 34.06 \\
H17 & 61.28 & 4.40 & 65.68 \\
H18 & 3.92 & 51.45 & 55.37 \\
H19 & 59.22 & 17.78 & 77.00 \\
H20 & 45.68 & 26.17 & 71.84 \\
\hline
\end{tabular}

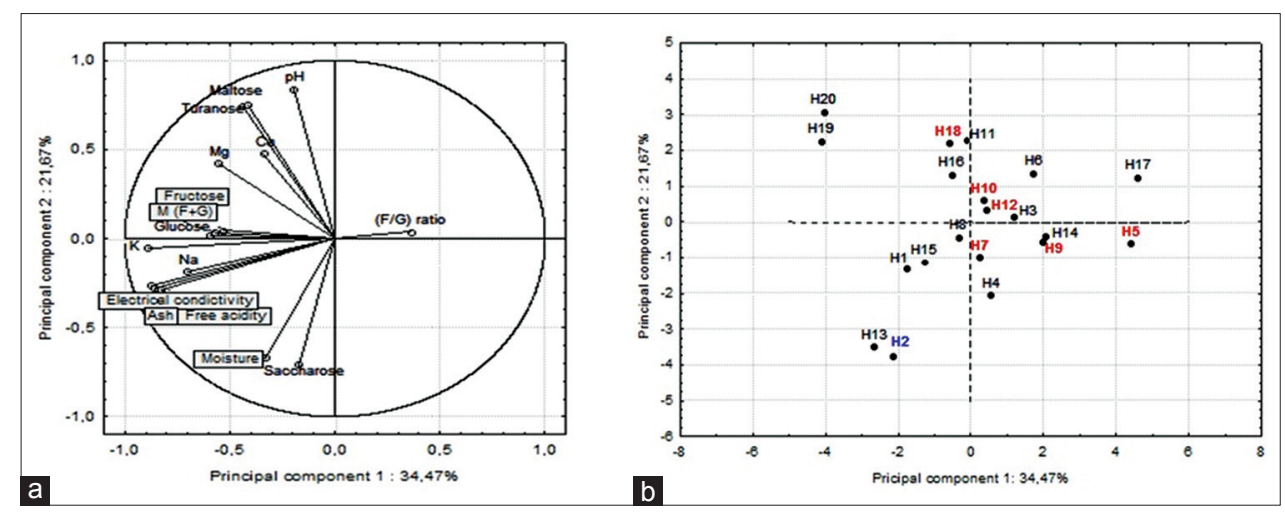

Fig 2. Principal component analysis: (a) Distribution of variables (physicochemical parameters and mineral content) on loadings plot. (b) Distribution of samples on scores plot.

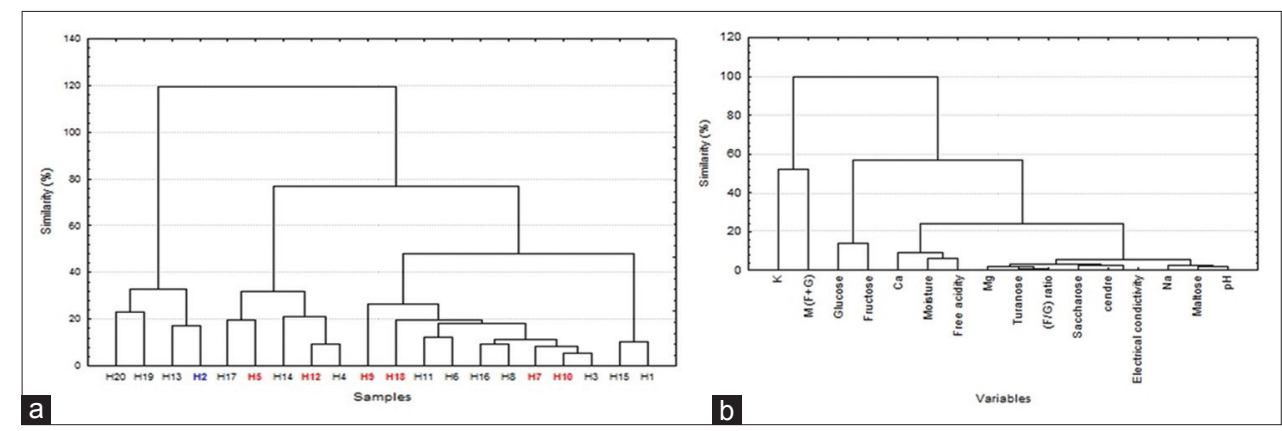

Fig 3. Dendogram of the complete linkage cluster analysis of: (a) the geographical origin of the semi-arid Algerian honey samples. (b) variables (physicochemical parameters and mineral content). 
with the geographical origin of samples. The latter have given more information on geographical origin of honeys.

A multivariate cluster analysis of variables exposed the presence of two distinct groups (at a similarity level of approximately $80 \%$ ) which correspond to physicochemical composition and mineral in a particular type of honey (Fig. 3b). The first cluster was composed of $\mathrm{K}$ and $\mathrm{M}$ $(F+G)$; while the second included glucose, fructose, $C a$, moisture, free acidity, $\mathrm{Mg}$, turanose, $(\mathrm{F} / \mathrm{G})$ ratio, sucrose, ash, electrical conductivity, $\mathrm{Na}$, maltose and $\mathrm{pH}$. This result shows a relationship between the sample origin and the clusters of variables.

\section{CONCLUSIONS}

In this study, physicochemical parameters and minerals were determined in twenty artisanal honey samples, from different semi-arid regions of North-east Algeria. The obtained results of physicochemical parameters agree with the requirements of European Community Directive. Moreover, studied samples are found to be very low in moisture and therefore they are safe from fermentation. Lower values of $\mathrm{K}, \mathrm{Ca}, \mathrm{Na}$ and $\mathrm{Mg}$ were obtained from several samples, which are probably due to the absence of dense vegetation cover and to the soil types of the investigated regions. A strong relationship between Electrical conductivity, free acidity and potassium was observed in this study. In view of the results obtained that the application of chemometric methods such as PCA and $\mathrm{CA}$ techniques, on the physicochemical parameters and major elements are insufficient to achieve a perfect classification of the different types of honey comes from same climate. This preliminary research has provided the groundwork for further analysis in order to determine the geographical origin of honey from semi-arid regions.

\section{ACKNOWLEDGEMENTS}

This work was funded by grants from the "Direction Générale de la Recherche Scientifique et du Développement Technologique" (DGRSDT). Thanks are given to all the beekeepers that have generously provided the honey samples to carry out this study.

\section{AUTHOR CONTRIBUTION}

The work presented here was carried out in collaboration between all authors. L. H. and A.T. defined the research subject and carried out the statistical treatment of the data; L. H., H. D., A. L., A. C. carried out the experimental part of this study. L. H., and C. A. wrote the paper..

\section{REFERENCES}

Ajlouni, S. and P. Sujirapinyokul. 2010. Hydroxymethylfurfuraldehyde and amylase contents in Australian honey. Food Chem. 119: 1000-1005.

Almeida-Silva, M., N. Canha, C. Galinha, H.M. Dung, M.C. Freitas and T. Sitoe. 2011. Trace elements in wild and orchard honeys. Appl. Radiat. Isotopes. 69: 1592-1595.

Amri, A. and A. Ladjama. 2013. Physicochemical characterization of some multifloral honeys from honeybees Apis mellifera collected in the Algerian northeast. Afr. J. Food Sci. 7: 168-173.

Anklam, E. 1998. A review of the analytical methods to determine the geographical and botanical origin of honey. Food Chem. 63: 549-562.

Belay, A., W.K. Solomon, G. Bultossa, N. Adgaba and S. Melaku. 2013. Physicochemical properties of the Harenna forest honey, Bale, Ethiopia. Food Chem. 141: 3386-3392.

Bogdanov, S., P. Martin and C. Lüllmann. 1997. Harmonised Methods of the European Honey Commission. Apidologie Extra Issue. 1-59.

Bogdanov, S., C. Lullmann, B.L. Mossel, B.R. D'Arcy, H. Russmann, G. Vorwohl, L. Oddo, A.G. Sabatini, G.L. Marcazzan, R. Piro, C. Flamini, M. Morlot, J. Lheretier, R. Borneck, P. Marioleas, A. Tsigouri, J. Kerkvliet, A. Ortiz, T. Ivanov, P. Vit, P. Martin and W. Von der Ohe. 1999. Honey quality and international regulatory standards: review by the international honey commission. Bee World. 802: 61-69.

Chefrour, A., R. Draiaia, A. Tahar, K.Y. Ait, S. Bennadja and M.J. Battesti. 2009. Physicochemical characteristics and pollen spectrum of some north-eastern Algerian honeys. Afr. J. Food Agric. Nutr. Dev. 9: 1276-1293.

Chudzinska, M. and D. Baralkiewicz. 2010. Estimation of honey authenticity by multielements characteristics using inductively coupled plasma-mass spectro-metry (ICP-MS) combined with chemometrics. Food Chem. Toxicol. 48: 284-290.

Conti, M.E. 2000. Lazio region (Central Italy) honeys: A survey of mineral content and typical quality parameters. Food Control. 11: 459-463.

Council of the European Union. 2002. Council Directive 2001/110/ EC of 20 December Relating to Honey. Official Journal of the European Communities 10: 47-52.

De Alda-Garcilope, C., A. Gallego-Picó, J.C. Bravo-Yagüe, R.M. Garcinuño-Martínez and P. Fernández-Hernando. 2012. Characterization of Spanish honeys with protected designation of origin "Miel de Granada" according to their mineral content. Food Chem. 135: 1785-1788.

Feás, X., J. Pires, M.L. Estevinho, A. Iglesias and J.P. Pinto de Araujo. 2010. Palynological and physicochemical data characterisation of honeys produced in the Entre-Douroe Minho region of Portugal. Int. J. Food Sci. Tech. 45: 1255-1262.

Finola, M.S., M.C. Lasagno and J.M. Marioli. 2007. Microbiological and chemical characterization of honeys from central Argentina. Food Chem. 100: 1649-1653.

Freitas, M.C., A.M.G. Pacheco and E. Ferreira. 2006. Nutrients and other elements on honey from Azores and mainland Portugal. J. Radioanal. Nucl. Chem. 270: 123-130.

Hernàndez, O.M., J.M.G. Fraga, A.I. Jiménez, F. Jiménez and J.J. Arias. 2005. Characterization of honey from the Canary Islands: Determination of the mineral content by atomic absorption spectrophotometry. Food Chem. 93: 449-458.

Kucuk, M., S. Kolayl, S.I. Karaoglu, E. Ulusoy, C. Baltac and F. Candan. 2007. Biological activities and chemical composition 
of three honeys of different types from Anatolia. Food Chem. 100: $526-534$

Lachman, J., D. Kolihova, D. Miholova, J. Kosata, D. Titera and K. Kult. 2007. Analysis of minority honey components: Possible use for the evaluation of honey quality. Food Chem. 101: 973-979.

Madejczyk, M. and D. Baralkiewicz. 2008. Characterization of Polish rape and honeydew honey according to their mineral contents using ICP-MS and F AAS/AES. Anal. Chim. Acta. 617: 11-17.

Makhloufi, C., J. D.Kerkvliet, G.R. D'Albore, A. Choukri and R. Samar. 2010. Characterization of Algerian honeys by palynological and physic-chemical methods. Apidologie. 41: 509-521.

Mateo, R. and F. Bosch-Reig. 1998. Classification of Spanish unifloral honeys by discriminant analysis of electrical conductivity, color, water content, sugars and $\mathrm{pH}$. J. Agric. Food Chem. 46(2): 393-400.

Molan, P.C. 1996. Authenticity of honey. In: Ashurst, P.R. and M.J. Dennis (Eds.), Food Authentication, University Press, London.

Nanda, V., B.C. Sarkar, H.K. Sharma and A.S. Bawa. 2003. Physicochemical properties and estimation of mineral content in honey produced from different plants in Northern India. J. Food Compos. Anal. 16: 613-619.

Nasiruddin Khan, M., M. Qaiser, S.M. Raza and M. Rehman. 2006. Physicochemical properties and pollen spectrum of imported and local samples of blossom honey from the Pakistani market. Int. J. Food Sci. Technol. 41: 775-781.

Ouchemoukh, S., P. Schweitzer, M. Bachir Bey, H. Djoudad-Kadji and H. Louaileche. 2010. HPLC sugar profiles of Algerian honeys. Food Chem. 121: 561-568.

Pisani, A., G. Protano and F. Riccobono. 2008. Minor and trace elements in different honey types produced in Siena County (Italy). Food Chem. 107: 1553-1560.

Rashed, M.N. and M.E. Soltan. 2004. Major and trace elements in different types of Egyptian mono-floral and non-floral bee honeys. J. Food Compos. Anal. 17: 725-735.

Ruoff, K., W. Luginbühl, S. Bogdanov, J.O. Bosset, B. Estermann, T. Ziolko, S. Kheradmandan and R. Amado. 2007. Quantitative determination of physical and chemical measurands in honey by near-infrared spectrometry. Eur. Food Res. Technol. 225: 415-423.

Silva, L.R., R. Videira, A.P. Monteiro, P. Valentão and P.B. Andrade. 2009. Honey from Luso region (Portugal): Physicochemical characteristics and mineral contents. Microchem. J. 93: 73-77.

Stankovska, E., T. Stafilov and R. Sajn. 2008. Monitoring of trace elements in honey from the Republic of Macedonia by atomic absorption spectrometry. Environ. Monit. Assess. 142: 117-126.

Sun, S., B. Guo, Y. Wei and M. Fan. 2011. Multi-element analysis for determining the geographical origin of mutton from different regions of China. Food Chem. 124: 1151-1156.

Terrab, A., A.F. Recamales, D. Hernanz and F.J. Heredia. 2004. Characterisation of Spanish thyme honeys by their physicochemical characteristics and mineral contents. Food Chem. 88: 537-542.

Torres, R.F., J.L. Perez-Bernal, M.A. Bello-Lopez, M. CallejonMochon, J.C. Jimenez-Sanchez and A. Guiraum-Perez. 2005. Mineral content and botanical origin of Spanish honeys. Talanta. 65: 686-691.

Tuzen, M., S. Silici, D. Mendil and M. Soylak. 2007. Trace element levels in honeys from different regions of Turkey. Food Chem. 103: 325-330.

Vanhanen, L.P., A. Emmertz and G.P. Savage. 2011. Mineral analysis of mono-floral New Zealand honey. Food Chem. 128: 236-240.

Yücel, Y. and P. Sultanoğlu. 2013. Characterization of Hatay honeys according to their multi element analysis using ICP-OES combined with chemometrics. Food Chem. 140: 231-237. 